\title{
A Mononuclear Nickel (II) Complex: Synthesis, X-ray Structure, Spectroscopic Characterization and Anti-tumor Activity
}

\author{
Sangharaj Diyali ${ }^{1}$, Ayan Kumar Mohanty ${ }^{2}$, Subhajit Sarkar ${ }^{1}$, Md. Firoj Hossain ${ }^{1}$, Biplab Bhowmik ${ }^{3}$, \\ Bhaskar Biswas $^{1 *}$
}

${ }^{1}$ Department of Chemistry, University of North Bengal, Darjeeling 734013, India

${ }^{2}$ Department of Biotechnology, University of North Bengal, Darjeeling 734013, India

${ }^{3}$ Department of Zoology, Diamond Harbour Women's University, West Bengal 743368, India

E-mail: bhaskarbiswas@nbu.ac.in, icbbiswas@gmail.com

Received: 18 December 2020; Revised: 4 January 2021; Accepted: 14 January 2021

\begin{abstract}
In this work, an effort has been made to examine the counteranionic behavior of thiocyanide ion towards the stabilization of a dicationic tris(2,2'-bipyridine)nickel (II) complex in the crystalline phase. The complex, $\left[\mathrm{Ni}(\text { bipy })_{3}\right] \cdot 2 \mathrm{NCS}$ (1) [bipy = 2,2'-bipyridine] was designed, synthesized and structurally characterized. The crystal structure analysis reveals that $\mathbf{1}$ crystallises in a hexagonal system with $P 6 /$ mcc space group and adopts an octahedral geometry. The nickel (II) complex exhibits important cytotoxic behaviour towards lung cancer cells (A549). $\mathrm{IC}_{50}$ value is calculated through MTT assay and determined as $131 \mu \mathrm{G} / \mathrm{mol}$. The relative percentage of morphological changes is further determined and $\sim 63 \%$ of the cells are destroyed through apoptosis mode within $24 \mathrm{~h}$ incubation.
\end{abstract}

Keywords: nickel (II), 2,2'-bipyridine, crystal structure, anti-tumor activity

\section{Introduction}

Metallo-intercalators act as a pivotal role in developing the chemistry of nucleic acids, especially for their importance in versatile applications like footprinting of DNA, design of structural probes, the development of therapeutic agents, etc [1-7]. Thus, enormous numbers of metallo-intercalators consisting of planar N-donor heterocyclics are widely utilized as vital chemical or photochemical reagents in the progress of nucleic acids chemistry. One of the renowned scientist groups, Barton and co-workers [1,8-12] contributed significantly to the chemical science of metallo-intercalators and charge transport in DNA with the photo-physical and biological studies of polypyridyl based metal complexes containing d-block metal ions. Meanwhile, Sigman and co-workers contributed immensely to chemical nuclease activities by designing metal-phenanthroline chelates [6, 13-17]. During the last few decades, 2,2'-bipyridine, 1,10-phenanthroline, terpyridine and others are widely employed as effective chelators in advanced chemical sciences [18]. Scientific studies illustrate that nickel-based coordination compounds play a pivotal role in DNA damage particularly in aging and cancerous activity [19-21]. It is also documented that nickel complexes show an important anti-proliferative effect against leukemic cells (HL-60), prostatic cells (PC-3) and human hepatocarcinoma cells (Hep-G2) [22]. Therefore, the design and exploration of anti-proliferative activity of the coordination compounds of nickel have been considered as an emerging area of biological and medicinal research [23-25].

Copyright (C2021 Bhaskar Biswas, et al.

DOI: https://doi.org/10.37256/acbr.112022752

This is an open-access article distributed under a CC BY license

(Creative Commons Attribution 4.0 International License)

https://creativecommons.org/licenses/by/4.0/ 
Among the transition metal ions, nickel (II) ion is very attractive towards the scientific community for its properties to serve as bio-enzymes like hydrolage, generator of $\mathrm{H}_{2}$ gas, etc. Among the available bio-relevant metalloenzymes, alkaline phosphatase enzyme contributes significantly to different biological functions ranging form DNA fragmentation to RNA replication to bone metabolism as well as bio-remediation of organophosphate pesticides [26]. Previously, several scientific groups made the effort to establish the crystal structures of tris(2,2'-bipyridine)nickel (II) in association with different counteranions like perchlorate, hexamolybdate, chloride, tetrachlorozincate and even 2-thiobarbiturate [27-31]. Herein, a tris(2,2'-bipyridine)nickel (II) thiocyanido complex has been synthesized and structurally characterized. Studies of its antitumor activities suggest that $\sim 63 \%$ of the cells are found as apoptosis in $24 \mathrm{~h}$ incubation which was assessed from the relative percentage of morphological changes for lung cancer cells (A549).

\section{Materials and methods}

\subsection{Starting materials}

Highly pure 2,2'-bipyridine (SRL, India), nickel (II) chloride hexahydrate (SRL, India), ammonium thiocyanide (SRL, India) and all the reagents, chemicals and solvents were procured from the reputed outlets and used as received.

\subsection{Physical measurements}

A FTIR-8400S spectrophotometer (SHIMADZU, Japan) with KBr palette was used to record FT-IR and a V-730 UV-Visible spectrophotometer (JASCO, Japan) was employed to measure the electronic spectrum in the solution phase. A Q-Tof-micro quadruple mass spectrometer (Waters Corporation, USA) was employed to record ESI-Ms spectrum. The $\mathrm{pH}$ value of the solutions was measured in PH meter (Systronics, India) at room temperature. A $2400 \mathrm{CHN}$ microanalyzer (Perkin Elmer, USA) was used to carry out elemental analyses.

\subsection{Synthesis of $\left[\mathrm{Ni}(\text { bipy })_{3}\right] \cdot 2 \mathrm{NCS}$ (1)}

A methanolic solution of bipyridine $(0.312 \mathrm{~g}, 2 \mathrm{mM})$ was mixed drop by drop to an aqueous solution of $\mathrm{NiCl}_{2}(0.240$ $\mathrm{g}, 1 \mathrm{mM})$ followed by addition of aqueous solution of $2 \mathrm{mM}$ of $\mathrm{NH}_{4} \mathrm{NCS}(0.152 \mathrm{~g})$. The pink coloured solution was kept in open atmosphere to obtain single crystals. Yield: $0.183 \mathrm{~g}\left(\sim 76 \%\right.$ based on metal salt). Anal. Calc. for $\mathrm{C}_{32} \mathrm{H}_{24} \mathrm{~N}_{8} \mathrm{~S}_{2} \mathrm{Ni}(\mathbf{1})$ : C, 59.74; H, 3.76; N, 17.42. Found: C, 59.79; H, 3.71; N, 17.47\%. IR (KBr, cm $\left.{ }^{-1}\right): 2071\left(\mathrm{v}_{\mathrm{NCS}}\right), 1638,1601\left(\mathrm{v}_{\mathrm{C}=\mathrm{N}}\right)$; UVVis $\left(\lambda_{\max }, \mathrm{Abs}, \mathrm{nm}, 10^{-4} \mathrm{M}, \mathrm{H}_{2} \mathrm{O}\right): 275,305,509,705$.

\subsection{X-ray diffraction analysis}

An XtaLABmini diffractometer (Rigaku Corporation, Japan) equipped with a Mercury375R $(2 \times 2$ bin mode) CCD detector was employed to collect X-ray diffraction data. The data were obtained on a graphite monochromated Mo-K $\alpha$ radiation $(\lambda=0.71073 \AA)$ at 293(2) K using w scans. The diffraction data were reduced with Crystal Clear suite. OLEX ${ }^{2}$ was used to determine the space group of the complex. Direct method was used to solve the crystal structure. The refinement of diffraction data was done by full-matrix least-squares procedures with the SHELXL-97 software package employing OLEX ${ }^{2}$ suite [32-33].

\subsection{Anticancer activity of the nickel (II) complex 2.5.1 Cell culture}

The cell line (A549 human lung cancer) was collected from the National Center for Cell Science, Pune, India. Dulbecco's Modified Eagle Medium (DMEM) high glucose medium (Sigma-Aldrich, USA) in supplement with 10\% fetal bovine serum (Gibco) was employed to culture the cells in 96-well culture plates. The culture plate was kept in a humidified atmosphere of $5 \% \mathrm{CO}_{2}$ at $37^{\circ} \mathrm{C}$ (Thermo Scientific, USA). The details of the experiment may be found elsewhere. 


\subsubsection{Cytotoxicity assay (MTT assay)}

The viability of A549 cells was tested by cell viability assay using MTT reagent [34], a colorimetric assay. The various concentrations of $\mathrm{Ni}$ (II) complex were prepared from stock solution of $\mathrm{Ni}$ (II) complex in dimethylsulfoxide (DMSO) diluted using DMEM media. Two hundred microliters of the sample was added to wells having $5 \times 10^{3}$ A549 cells per well. DMSO was considered as the solvent control. Twenty $\mu \mathrm{L}$ of MTT solution $(5 \mathrm{mg} / \mathrm{mL}$ in poly butylene succinate (PBS)) was added to the well and the plate was wrapped in aluminum foil. Then, it was incubated at $37^{\circ} \mathrm{C}$ for $4 \mathrm{~h}$. The formazan product was dissolved by the addition of $100 \mu \mathrm{L}$ of DMSO to the well. The absorbance was monitored at $570 \mathrm{~nm}$ (measurement) and $630 \mathrm{~nm}$ (reference) using a 96-well plate reader (Bio-Rad, iMark, USA). Data were collected for three replicates each and used to calculate the respective mean. The percentage inhibition was determined following the formula:

$$
=\frac{[\text { Mean OD of untreated cells }(\text { control })-\text { Mean OD of treated cells }(\text { treated })] \times 100}{\text { Mean absorbance of untreated cells }(\text { control })}
$$

The $\mathrm{IC}_{50}$ value which was calculated using viability against concentration plot $\left(\mathrm{IC}_{50}\right.$ is the concentration at which the complex killed $50 \%$ of the cells) for $24 \mathrm{~h}$ was determined.

\subsubsection{Acridine orange $(A O)$ and ethidium bromide $(E B)$ staining}

The apoptosis or cell death was evaluated by the staining method described by Spector et al. [34]. The cells were treated with an $\mathrm{IC}_{50}$ concentration of the nickel complex for $24 \mathrm{~h}$. After incubation, the cells were harvested and cold PBS was used to wash the cells. Cell pellets were re-suspended and diluted with PBS to a concentration of $5 \times 10^{5}$ cells/ $\mathrm{mL}$ and mixed with $25 \mu \mathrm{L}$ of AO/EB solution ( $3.8 \mu \mathrm{M}$ of AO and $2.5 \mu \mathrm{M}$ of EB in PBS) on clean microscope slide and immediately examined under an Axio scope 2 plus fluorescent microscope (Zeiss, Japan) with UV filter (450-490 nm). Among the 300 cells for each sample, viability was checked through apoptosis or necrosis following the staining of membrane integrity and nucleus structure.

\section{Results and discussion}

\subsection{Synthesis and formulation}

The octahedral nickel (II) complex was produced by adding 2,2'-bipyridine to nickel (II) chloride followed by ammonium thiocyanide in an aqueous-methanolic solution at room temperature. Previously, Czakis-Sulikowska et al. prepared similar type of nickel (II)-thiocyanate complex in reaction with 4,4'-bipyridine in aq. ethanolic medium [35]. The primary zone of coordination for $\mathbf{1}$ was defined by mainly X-ray diffraction study and other spectroscopic and analytical methods. The pink coloured single crystals were isolated after a couple of days. The structural formulations were confirmed by different analytical techniques, and X-ray diffraction analysis.

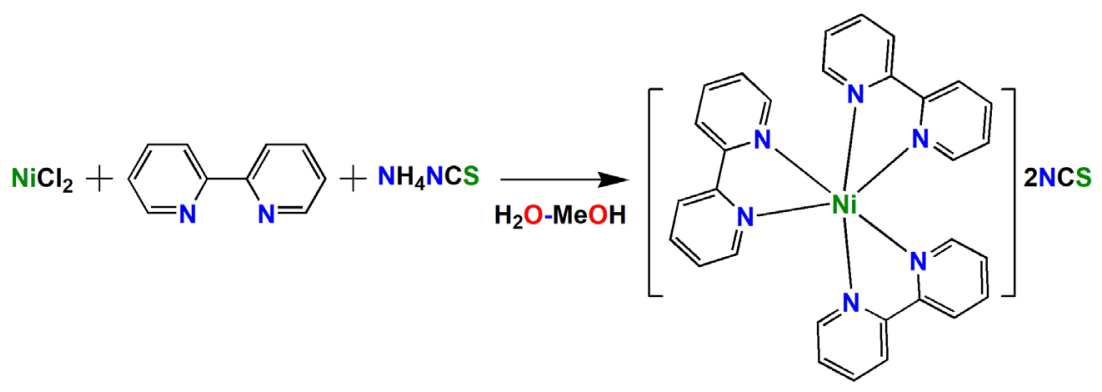

Figure 1. Preparative route for the nickel (II) complex (1) 


\subsection{Crystal structure of [Ni(bipy) $\left.]_{3}\right] \cdot 2 \mathrm{NCS}$ (1)}

The X-ray structure of mononuclear Ni (II) complex indicates that mononuclear Ni (II) complex exists in a hexagonal crystal system with $P 6 /$ mcc space group and adopts a distorted octahedral geometry. An Oak Ridge Thermal Ellipsoid Plot (ORTEP) view of 1 with 30\% ellipsoidal probability is shown in Figure 2. Both the axial and equatorial planes around the Ni (II) centre are formed by nitrogen atoms of the three bipyridine ligands. The dicationic charge of nickel (II)-bipyridine chelate is counterbalanced by two units of thiocyanate ions. The crystallographic structural parameters of $\mathbf{1}$ are listed in Table 1. The metal centric selected bond lengths and angles are presented in Table 2.

Scientific documents show that Hong et al., Zhang et al., Rui Perez et al. reported the crystal structures of tris(2,2'bipyridine)nickel (II) chelate in combination with percholarate, molybdate and chloride anions respectively [27-28, 30]. The reported crystal structures showed different crystal systems and space groups and a comparison of structural refinement parameters between the reported structures and our structure is given in Table 3. In our crystal structure, the thiocyanate ions get distorted although we made several attempts to refine the structure. However, we have confirmed the existence of thiocyanate through IR and elemental analysis.

Table 1. Crystallographic refinement parameters of [Ni(bipy) $)_{3} \cdot 2 \mathrm{NCS}(\mathbf{1})$

\begin{tabular}{cc}
\hline Crystal parameters & $\mathbf{1}$ \\
\hline Empirical formula & $\mathrm{C}_{31} \mathrm{H}_{24} \mathrm{~N}_{7} \mathrm{SNi}$ \\
Formula weight & 584.7 \\
Temperature & $293 \mathrm{~K}$ \\
Wavelength & $0.71073 \AA$ \\
Crystal system & Hexagonal \\
Space group & $\mathrm{P} 6 / \mathrm{mcc}$ \\
Unit cell dimensions & $\mathrm{a}=13.3747(19) \AA$ \\
& $\mathrm{b}=13.3747(19) \AA$ \\
Volume & $\mathrm{c}=21.440(4) \AA$ \\
Z & $3321.4(9) \AA^{3}$ \\
Density (calculated) & 8 \\
Absorption coefficient & $1.110 \mathrm{Mg} / \mathrm{m}^{3}$ \\
F (000) & $1.335 \mathrm{~mm}^{-1}$ \\
Reflections collected & 1152 \\
Independent reflections & 6964 \\
$\mathrm{R}$ (int) & 1122 \\
Goodness-of-fit on F & 0.035 \\
R indices (all data) & 1.08 \\
Largest diff. peak and hole & $0.0504, \mathrm{wR} 2=0.170$ \\
\hline & $\mathrm{and} \mathrm{-0.40} \mathrm{e.} \AA^{-3}$ \\
\hline
\end{tabular}

Table 2. Metal centric bond lengths $(\AA)$ and bond angles $\left(^{\circ}\right)$ for $\left[\mathrm{Ni}(\text { bipy })_{3}\right] \cdot 2 \mathrm{NCS}$ obtained from the XRD structure

\begin{tabular}{ccc}
\hline & \multicolumn{2}{c}{ Bond lengths $(\AA)$} \\
\hline Ni1-N1 & Bond angles \\
\hline & N1-Ni1-N1*a & $94.35(10)$ \\
& N1-Ni1-N1*c & $78.64(9)$ \\
& N1-Ni1-N1*d & $169.86(12)$ \\
& N1-Ni1-N1*e & $93.50(10)$ \\
\hline
\end{tabular}




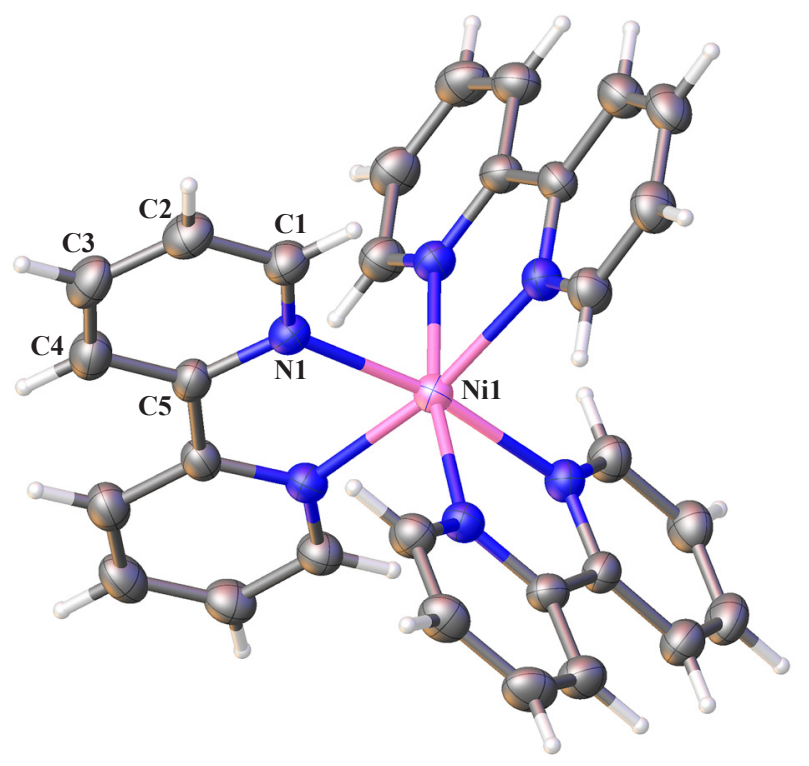

Figure 2. An ORTEP diagram of the dicationic $\left[\mathrm{Ni}(\text { bipy })_{3}\right]^{2+}$ with $30 \%$ ellipsoidal probability

Table 3. A comparison of structural refinement parameters of $\left[\mathrm{Ni}(\text { bipy })_{3}\right] \cdot 2 \mathrm{NCS}(\mathbf{1})$ with the previously reported structures

\begin{tabular}{ccccc}
\hline Parameter & {$\left[\mathrm{Ni}(\text { bipy })_{3}\right] \mathrm{Cl}_{2}([30])$} & {$\left[\mathrm{Ni}(\text { bipy })_{3}\right] \cdot 2 \mathrm{ClO}_{4}([27])$} & {$\left[\mathrm{Ni}(\text { bipy })_{3}\right]\left[\mathrm{ZnCl}_{4}\right]([31])$} & This work* \\
\hline Crystal system & Monoclinic & Monoclinic & Trigonal & Hexagonal \\
Space group & $\mathrm{C} 2 / \mathrm{c}$ & $\mathrm{C} 2 / \mathrm{c}$ & $\mathrm{R} 3 \mathrm{c}$ & $\mathrm{P} 6 / \mathrm{mcc}^{*}$ \\
$\mathrm{Z}$ & 4 & 4 & 12 & 8 \\
Unit cell dimensions & & & $13.34 .3(2)$ & $13.3747(19)$ \\
$\mathrm{a}(\AA)$ & $13.410(2)$ & $17.502(2)$ & & $13.3747(19)$ \\
$\mathrm{b}(\AA)$ & $22.509(4)$ & $10.777(1)$ & $58.932(12)$ & $21.440(4)$ \\
$\mathrm{c}(\AA)$ & $23.781(4)$ & $16.092(2)$ & $9087(3)$ & $3321.4(9)$ \\
$\mathrm{V}\left(\AA^{3}\right)$ & $6921(2)$ & $3034.8(6)$ &
\end{tabular}

\subsection{Solution phase behavior of the nickel (II) complex}

The absorption spectrum of the tris(bipy)nickel (II) complex was measured in aqueous phase at room temperature. The electronic spectrum displayed that the two well resolved ligand field transitions at 705 and $509 \mathrm{~nm}$ in the visible range corresponding to the spin-allowed ${ }^{3} \mathrm{~A}_{2 \mathrm{~g}} \rightarrow{ }^{3} \mathrm{~T}_{2 \mathrm{~g}}$, and ${ }^{3} \mathrm{~A}_{2 \mathrm{~g}} \rightarrow{ }^{3} \mathrm{~T}_{1 \mathrm{~g}}(\mathrm{~F})$ electronic transitions respectively. This spectrum resembles very well with the electronic spectrum of the tris(2,2'-bipy)nickel (II) tetrafluoroborate complex reported by Abramov. The electronic transition, ${ }^{3} \mathrm{~A}_{2 \mathrm{~g}} \rightarrow{ }^{3} \mathrm{~T}_{1 \mathrm{~g}}(\mathrm{~F})$ is responsible for the development of pink color. Other electronic transitions at 275 and $305 \mathrm{~nm}$ are assignable to $\pi \rightarrow \pi$ or $\mathrm{n} \rightarrow \pi$ transitions of bipyridine ligands.

\subsection{Antiproliferative activity of the nickel (II) complex}

\subsubsection{MTT Assay}

The human A549 lung cancer cell line was considered to examine the cytotoxic activities of the Ni (II) complex following MTT assay [36]. The cytotoxic effect was studied based on dose-dependent manner which helps to determine 
the $\mathrm{IC}_{50}$ in comparison with untreated cells. The $\mathrm{IC}_{50}$ value for $24 \mathrm{~h}$ was calculated as $131 \pm 0.5 \mu \mathrm{G} / \mathrm{mL}$ and the results of MTT assay indicated that the nickel (II) complex is moderately toxic towards A549 cells (Figure 3).

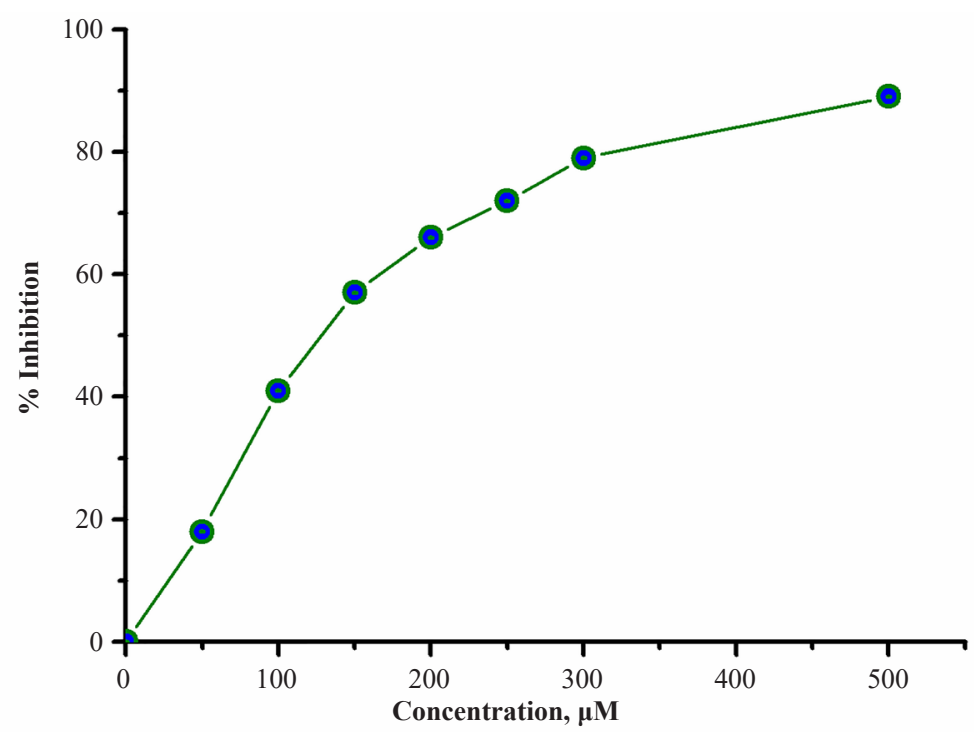

Figure 3. Cytotoxic effect of the $\left[\mathrm{Ni}(\text { bipy })_{3}\right] \cdot 2 \mathrm{NCS}$ complex on A549 cells after exposure for $24 \mathrm{~h}$

\subsubsection{AO/EB staining}

The morphological changes in the apoptosis induced by the nickel (II) complex were determined by AO/EB staining. The early and late apoptosis of A549 cancer cell line in treatment with synthetic tris(chelate)nickel (II) complex for $24 \mathrm{~h}$ was observed with AO/EB double-stained method and shown in Figure 4. It is commonly observed that the viable cells display a green fluorescence which indicates the normal intact cell membrane featuring uniform chromatin. However, a bright green region with yellowish-green colour presents the early apoptosis cells which recommend the nuclear fragmentation with apoptotic bodies outside the cell membrane. The orange-yellow colour in AO/EB staining suggests the late apoptosis cells with fragmented chromatin. The AO/EB results suggest that the nickel (II) complex induced the majority of cell death through apoptosis mode and very fewer in necrosis for $24 \mathrm{~h}$ treatment (Figure 5). Cell shrinkage, chromatin condensation, and fragmentation were also observed in $\mathrm{Ni}$ (II) complex treated cells. This finding is correlated with the MTT assay (Figure 3).
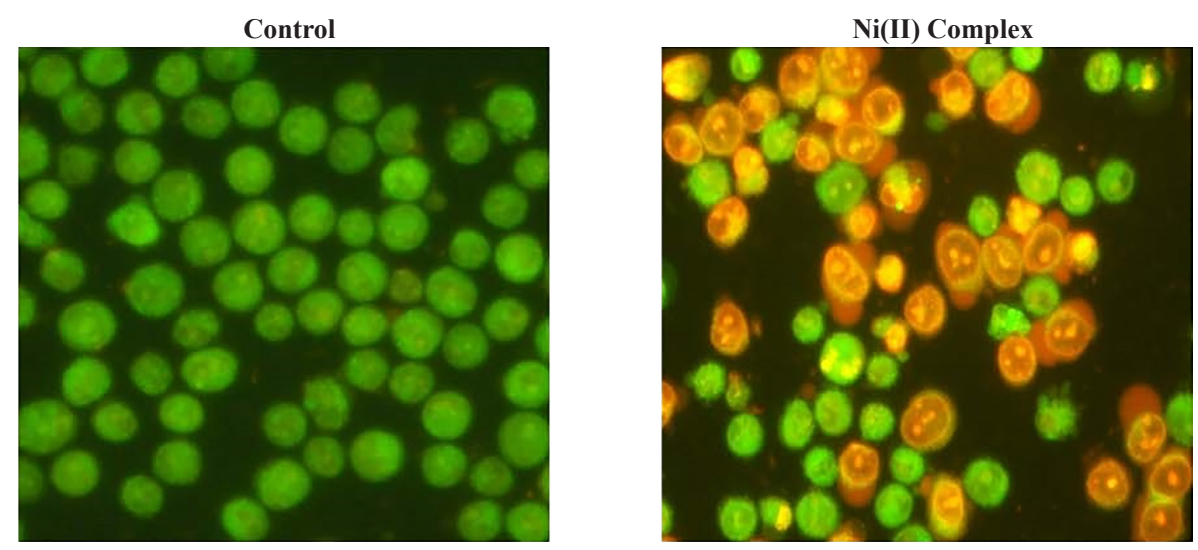

Figure 4. Representative morphological changes produced in A549 human lung cancer cells by [Ni(bipy) ${ }_{3} \cdot 2 \mathrm{NCS}$ (1) with AO/EB staining after $24 \mathrm{~h}$ incubation 


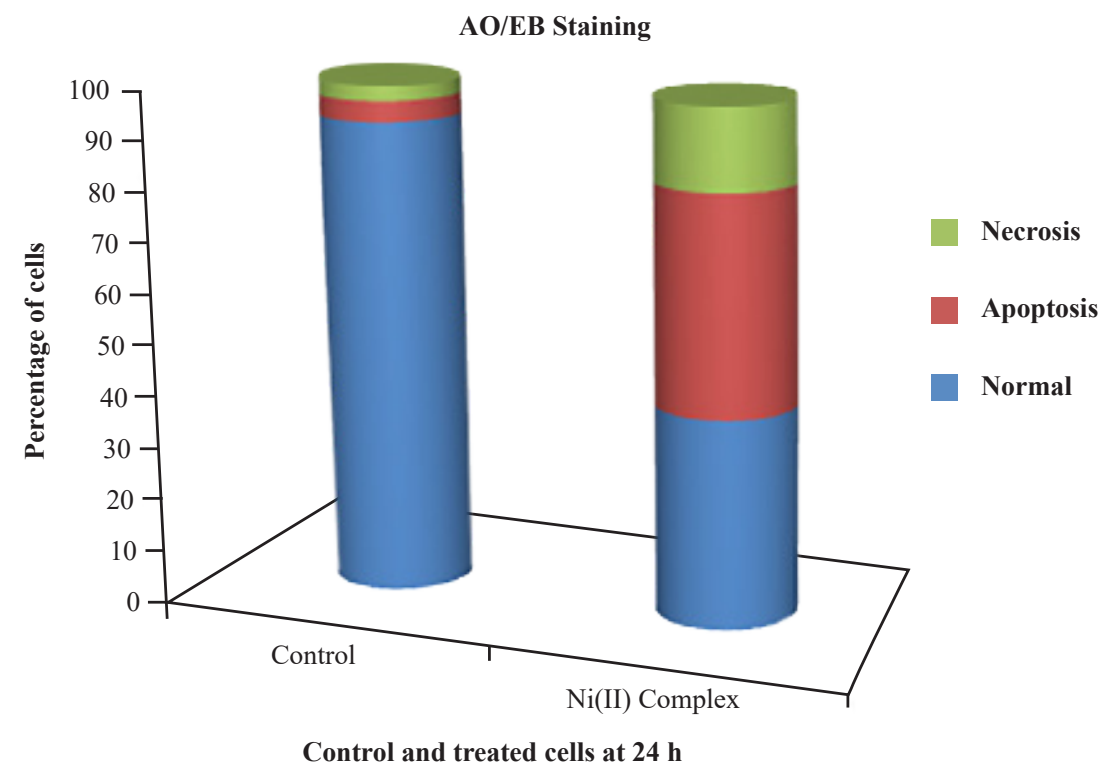

Figure 5. Relative percentage of morphological changes by the treatment of [Ni(bipy) $\left.{ }_{3}\right] \cdot 2 \mathrm{NCS}(\mathbf{1})$ with A549 human lung cancer cell following $\mathrm{AO} / \mathrm{EB}$ staining

\section{Conclusions}

To summarize, a mononuclear octahedral nickel (II)-phenanthroline complex, [Ni(bipy) $)_{3} \cdot 2 \mathrm{NCS}$ (1) was prepared and structurally characterized using different analytical techniques and computational modeling. The crystal structural analysis indicates that nickel (II) complex was crystallized in a hexagonal system and adopted an octahedral geometry. The nickel (II) complex exhibited important cytotoxic behaviour towards lung cancer cells (A549) and $\mathrm{IC}_{50}$ value was calculated through MTT assay and determined the value as $131 \mu \mathrm{G} / \mathrm{mol}$. The changes in apoptosis and necrosis were observed through changes in relative percentage of morphological behavior which ensures that $\sim 63 \%$ of the cells are destroyed compared to the control cells after $24 \mathrm{~h}$ incubation.

\section{Supplementary data}

Supplementary crystallographic data are available free of charge from The Director, CCDC, 12 Union Road, Cambridge, CB2 1EZ, UK (fax: +44-1223-336033; E-mail: deposit@ccdc.cam.ac.uk or www: http://www.ccdc.cam. ac.uk) upon request, quoting deposition number CCDC 2050513 for the nickel (II) complex $\mathbf{1}$.

\section{References}

[1] Erkkila K, Odom D, Barton J. Recognition and reaction of metallointercalators with DNA. Chemical Reviews. 1999; 99: 2777-2796.

[2] Armitage B. Photocleavage of nucleic acids. Chemical Reviews. 1998; 98: 1171-1200.

[3] Pogozelski W, Tullius T. Oxidative strand scission of nucleic acids: Routes initiated by hydrogen abstraction from the sugar moiety. Chemical Reviews. 1998; 98: 1089-1108.

[4] Burrows C, Muller J. Oxidative nucleobase modifications leading to strand scission. Chemical Reviews. 1998; 98 : $1109-1152$.

[5] McMillin D, McNett K. Photoprocesses of copper complexes that bind to DNA. Chemical Reviews. 1998; 98 : 1201-1220.

[6] Sigman D, Bruice T, Mazumder A and Sutton C. Targeted chemical nucleases. Accounts of Chemical Research. 
1993; 26: 98-104.

[7] Pratviel G, Bernadou J, Meunier B. DNA and RNA cleavage by metal complexes. Advanced Inorganic Chemistry. 1998; 45: 251-312

[8] Pyle AM. Barton JK. Probing nucleic acids with transition metal complexes. Progress in Inorganic Chemistry. 1990; 38: 413-475.

[9] Barton J. Metals and DNA: Molecular left-handed complements. Science. 1986; 233: 727-734.

[10] Barton JK, Raphael AL. Site-specific cleavage of left-handed DNA in pBR322 by lambda-tris (diphenyl phenanthroline) cobalt (III). Proceedings of the National Academy of Sciences of the United States of America. 1985; 82: 6460-6464.

[11] Delaney S, Pascaly M, Bhattacharya P, Han K and Barton J. Oxidative damage by ruthenium complexes containing the dipyridophenazine ligand or its derivatives: A focus on intercalation. Inorganic Chemistry. 2002; 41: 19661974.

[12] Sontz P, Muren N, Barton J. DNA charge transport for sensing and signaling. Accounts of Chemical Research. 2012; 45: 1792-1800.

[13] Sigman D, Mazumder A, Perrin D. Chemical nucleases. Chemical Reviews. 1993; 93: 2295-2316.

[14] Sigman D. Nuclease activity of 1,10-phenanthroline-copper ion. Accounts of Chemical Research. 1986; 19: 180186.

[15] Sigman D, Graham D, D'Aurora V and Stern A. Oxygen-dependent cleavage of DNA by the 1,10-phenanthroline. cuprous complex. Inhibition of escherichia coli DNA polymerase I. Journal of Biological Chemistry. 1979; 254: 12269-12272.

[16] Zelenko O, Gallagher J, Sigman D. Scission of DNA with Bis (1,10-phenanthroline) copper without intramolecular hydrogen migration. Angewandte Chemie International Edition in English. 1997; 36: 2776-2778.

[17] Zelenko O, Gallagher J, Xu Y, Sigman D. Chemical nuclease activity of 1,10-phenanthroline-copper. Isotopic probes of mechanism. Inorganic Chemistry. 1998; 37: 2198-2204.

[18] Reedijk J, Wilkinson G, Gillard RD and McCleverty JA. Comprehensive Coordination Chemistry, Pergamon Press, Oxford. 1987; 2: 73.

[19] Saleem K, Wani W, Haque A, Lone M, Hsieh M, Jairajpuri M, et al. Synthesis, DNA binding, hemolysis assays and anticancer studies of copper (II), nickel (II) and iron (III) complexes of a pyrazoline-based ligand. Future Medicinal Chemistry. 2013; 5: 135-146.

[20] Muralisankar M, Haribabu J, Bhuvanesh N, Karvembu R and Sreekanth A. Synthesis, X-ray crystal structure, DNA/protein binding, DNA cleavage and cytotoxicity studies of N (4) substituted thiosemicarbazone based copper (II)/nickel (II) complexes. Inorganica Chimica Acta. 2016; 449: 82-95.

[21] Haleel A, Arthi P, Dastagiri RN, Veena V, Sakthivel N, Arun Y, et al. DNA binding, molecular docking and apoptotic inducing activity of nickel (II), copper (ii) and zinc (ii) complexes of pyridine-based tetrazolo [1,5-a] pyrimidine ligands. RSC Advances. 2014; 4: 60816-60830.

[22] Zhu T, Wang Y, Ding W, Xu J, Chen R, Xie J, et al. Anticancer activity and DNA-binding investigations of the Cu (II) and Ni (II) complexes with coumarin derivative. Chemical Biology \& Drug Design. 2014; 85: 385-393.

[23] Alomar K, Landreau A, Allain M, Bouet G, Larcher G. Synthesis, structure and antifungal activity of thiophene2,3-dicarboxaldehyde bis(thiosemicarbazone) and nickel (II), copper(II) and cadmium(II) complexes: Unsymmetrical coordination mode of nickel complex. Journal of Inorganic Biochemistry. 2013; 126: 76-83.

[24] Ramírez-Macías I, Maldonado C, Marín C, Olmo F, Gutiérrez-Sánchez R, Rosales M, et al. In vitro anti-leishmania evaluation of nickel complexes with a triazolopyrimidine derivative against leishmania infantum and leishmania braziliensis. Journal of Inorganic Biochemistry. 2012; 112: 1-9.

[25] Betanzos-Lara S, Gómez-Ruiz C, Barrón-Sosa L, Gracia-Mora I, Flores-Álamo M, Barba-Behrens N. Cytotoxic copper (II), cobalt (II), zinc (II), and nickel (II) coordination compounds of clotrimazole. Journal of Inorganic Biochemistry. 2012; 114: 82-93.

[26] Kojima T, Morimoto T, Sakamoto T, Miyazaki S and Fukuzumi S. Ruthenium (II) pyridylamine complexes with diimine ligands showing reversible photochemical and thermal structural change. Chemistry-A European Journal. 2008; 14: 8904-8915.

[27] Zhou Y, Li X, Xu Y, Cao R and Hong M. Tris(2,2'-bipyridine)nickel (II) diperchlorate. Acta Crystallographica Section E Structure Reports Online. 2003; 59: m300-m302.

[28] Fan L, Wei P, Pang S and Zhang X. Tris(2,2'-bipyridine)nickel (II) hexamolybdate. Acta Crystallographica Section E Structure Reports Online. 2010; 66: m1119-m1119.

[29] Golovnev N, Molokeev M, Sterkhova I, Lesnikov M and Samoilo A. Structure of bis (2-Thiobarbiturate) Tris(2,2- 
Bipyridyl) Nickel (II) Hexahydrate. Journal of Structural Chemistry. 2019; 60: 111-116.

[30] Ruiz-Pérez C, Lorenzo Luis P, Lloret F and Julve M. Dimensionally controlled hydrogen-bonded nanostructures: synthesis, structure, thermal and magnetic behaviour of the tris-(chelated) nickel (II) complex [Ni(bipy)3] $\mathrm{Cl} 2 \cdot 5.5 \mathrm{H} 2 \mathrm{O}$ (bipy $=2,2^{\prime}$-bipyridyl). Inorganica Chimica Acta. 2002; 336: 131-136.

[31] Lin SH, Wang ZK, Zhang BH, Hu HM and Huang, JS. Crystal structure of tris(2,2'-bipyridine)nickel (II) tetrachlorozincate. Chinese Journal of Chemistry. 2000; 19: 95-98.

[32] CrystalClear 2.0. Japan, Tokyo: Rigaku Corporation.

[33] (a) Sheldrick G. A short history of SHELX. Acta Crystallographica Section A Foundations of Crystallography. 2007; 64: 112-122. (b) Dolomanov O, Bourhis L, Gildea R, Howard J and Puschmann H. OLEX2: A complete structure solution, refinement and analysis program. Journal of Applied Crystallography. 2009; 42: 339-341.

[34] Spector DL, Goldman RD, Leinwand LA. Cell: A laboratory manual. Culture and Biochemical Analysis of Cells. New York: Cold Spring Harbor Laboratory Press; 1998.

[35] Czakis-Sulikowska D, Katuzna J. Synthesis and thermal behaviour of 4,4'-bipyridyl and 2,4'bipyridyl complexes of Co (II), Ni (II) and Cu (II) thiocyanates. Journal of Thermal Analysis. 1996; 47: 1763-1776.

[36] Mosmann T. Rapid colorimetric assay for cellular growth and survival: Application to proliferation and cytotoxicity assays. Journal of Immunological Methods. 1983; 65: 55-63. 